\title{
GENETIC DIVERGENCE AMONG HYBRIDS OF 'CRAVO' MANDARIN WITH 'PÊRA' SWEET ORANGE
}

\author{
Roberto Pedroso de Oliveira' ${ }^{1,3 *}$; Carlos Ivan Aguilar-Vildoso; Marcos Antônio Machado \\ ${ }^{1}$ Embrapa Clima Temperado, C.P. 403 - CEP: $96001-970$ - Pelotas, RS. \\ ${ }_{3}^{2}$ Centro de Citricultura 'Sylvio Moreira', C.P. 04 - CEP: 13490-970 - Cordeirópolis, SP. \\ ${ }^{3} \mathrm{CNPq}$ Fellow. \\ *Corresponding author <rpedroso@cpact.embrapa.br>
}

\begin{abstract}
Molecular markers have been used as tools in breading programs of sexual hybridation, allowing the genetic characterization of a large number of genotypes. The RADP markers are the most used since the employed techniques are simple and of low cost. To evaluate the genetic divergence among $F$, hybrids of 'Cravo' mandarin (Citrus reticulata Blanco) and 'Pêra' sweet orange ( $C$. sinensis (L.) Osbeck), this study analyses the variability and similarity of the hybrids among themselves and with their parents. Random Amplified Polimorfic DNA marker analysis, with 102 primers, were applied to a population composed of 94 hybrids and their parents. Multivariate genetic divergence analysis of the principal components and Tocher grouping were carried out only considering the polymorphic fragments. Genetic distances were calculated by the arithmetic complement of the Jaccard index. Bidimensional dispersion graphs among hybrid and parent distances and of the divergence analysis by principal components were constructed. High genetic similarity among Cravo and Pêra varieties and their hybrids was verified, showing a casual distribution from the hybrids in relation to the parents, but in intermediary positions. The principal component analysis showed little applicability in the study of hybrid genetic divergence. The hybrids and parents were classified in groups based on the genetic similarity, using the Tocher optimization method.
\end{abstract}

Key words: Citrus reticulata, Citrus sinensis, Tocher grouping, RAPD, citrus

\section{DIVERGÊNCIA GENÉTICA ENTRE HÍBRIDOS DE TANGERINA 'CRAVO' COM LARANJA 'PÊRA'}

\begin{abstract}
RESUMO: Os marcadores moleculares têm sido utilizados como ferramentas em programas de melhoramento por hibridação sexual, permitindo a caracterização genética de grande número de genótipos. Os marcadores moleculares RAPD são os mais utilizados pois as técnicas empregadas são simples e de baixo custo. Avaliouse a divergência genética entre híbridos $\mathrm{F}_{1}$ de tangerina 'Cravo' ( Citrus reticulata Blanco) com laranja 'Pêra' (C. sinensis (L.) Osbeck) e estudou-se a variabilidade e a similaridade desses materiais entre si e em relação aos parentais. Reações RAPD, com 102 primers, foram realizadas em uma população de 94 híbridos e nos parentais. As análises multivariadas de divergência genética de componentes principais e agrupamento de Tocher foram realizadas, considerando-se, somente, os fragmentos polimórficos. As distâncias genéticas foram obtidas por meio do complemento aritmético do índice deJaccard. Gráficos bidimensionais de dispersão das distâncias dos híbridos e parentais e da análise de divergência por meio de componentes principais foram construídos. Verificou-se elevada similaridade genética entre as variedades Cravo e Pêra e seus híbridos, demonstrando uma distribuição praticamente aleatória dos híbridos em relação aos parentais, porém em posições intermediárias. A análise de componentes principais apresentou aplicabilidade reduzida no estudo da divergência genética dos híbridos. O método de otimização de Tocher possibilitou a classificação dos híbridos e parentais em função de sua similaridade genética.

Palavras-chave: Citrus reticulata, Citrus sinensis, agrupamento de Tocher, RAPD, citros
\end{abstract}

\section{INTRODUCTION}

The history of citriculture shows a need to search for new varieties, because the genetic base of the economically important species is narrow, even though the genetic diversity in the citrus group is wide.

Controlled crosses have been performed since the 19th century, and some economically important hybrids have been obtained (Moreira \& Pio, 1991). The discontinuity of breeding programs as well as biological factors, such as prolonged juvenility, self-incompatibility and incompatibility between some species, high heterozygosity, sterility, depression by endogamy, apomixis and polyploidy have been the major limitations found in obtaining new citrus varieties (Grosser \& Gmitter Jr., 1990).

Several molecular markers have been utilized as tools in breeding programs by sexual hybridization, allowing the genetic characterization of a large number of genotypes by means of procedures that are relatively simple, fast and free of interferences in the environment. RAPD (Random Amplified Polymorphic DNA) markers (Williams et al., 1990) are among the most utilized markers, since they are produced by techniques that are simple, inexpensive and relatively less labor-intensive (Huff et al., 1993). 
A citrus breeding program targeted at obtaining new varieties is being conducted at Centro de Citricultura 'Sylvio Moreira' (CCSM- IAC), Cordeirópolis-SP, in cooperation with Embrapa Clima Temperado, PelotasRS. A population of 'Cravo' mandarin (Citrus reticulata Blanco) hybrids, female parent, with 'Pêra' sweet orange (C. sinensis (L.) Osbeck) was obtained by means of controlled crosses. These hybrids should have high genetic variability and could be important since they segregate for several traits of agronomic value.

Obtaining a knowledge and quantifying the genetic variability in a population is important for breeders to study the genetic relationships between hybrids and parents, and could provide orientation in selecting promising materials, new crosses and an understanding of how several characters are inherited.

Different multivariate statistics techniques, such as principal components, principal coordinates, and canonic variables analyses, and agglomerative methods, such as Tocher's, have been utilized in genetic divergence studies (Dias, 1994; Cruz, 2001). These have allowed more precise inferences on genetic relationships between genotypes, since they consider the correlations that exist in a set of characters that combine multiple pieces of information.

The objective of this work was to evaluate the genetic divergence between $F_{1}$ hybrids and the parental 'Cravo' mandarin and 'Pêra' sweet orange.

\section{MATERIAL AND METHODS}

The parental 'Cravo' mandarin and 'Pêra' sweet orange, and a population of $94 \mathrm{~F}_{1}$ hybrids of these varieties, obtained by means of controlled crosses, were utilized in this genetic divergence study.

The RAPD analyses were performed according to Oliveira et al. (2002), and 102 arbitrary sequence decamer primers from kits $A, A B, A T, A V, B, C, D, E, G$, $\mathrm{H}, \mathrm{I}, \mathrm{M}, \mathrm{N}, \mathrm{P}, \mathrm{Q}, \mathrm{R}, \mathrm{U}$ and $\mathrm{Y}$ of Operon Technologies Inc were utilized.

The polymorphic DNA fragments between 'Cravo' mandarin and 'Pêra' sweet orange $(\mathrm{Aa} \times$ aa and aa $\times \mathrm{Aa})$ and those monomorphic $(\mathrm{Aa} \times \mathrm{Aa})$ that would segregate in the progeny, were evaluated based on their presence or absence in the genotypes.

The GENE application (Cruz, 2001) was utilized in the multivariate analyses. Initially, Jaccard's coefficient (Sneath \& Sokal, 1973), recommended for dominant character markers, such as RAPD (Link et al., 1995), was utilized to estimate the genetic similarity between hybrids and parents. Then, the genetic distances were obtained by the arithmetic complement of Jaccard's coefficient, and were utilized to create a bidimensional dispersion graph (Cruz, 2001).

The genetic divergence analysis between hybrids and the parents was performed by means of principal components analysis (Pearson, 1901) and Tocher's cluster optimization methods (Rao, 1952), based on the genetic distances matrix.

The principal components analysis was made by reducing the dimensions of the group of data to produce a smaller number of abstract variables, thus maximizing the variance of the linear combinations of the variables (Cruz \& Regazzi, 1994).

For this analysis, the original variables data were transformed according to the formula $X=X i / S X$, where $X$ is the standardized variable, $X i$ is the original variable and $S x$ is the standard deviation of variable $X$ (Cruz, 2001). The first four principal components were utilized to plot the genotypes on two bidimensional dispersion graphs.

For Tocher's optimization method, the adopted criterion was that the mean of dissimilarity measurements within each group had to be smaller than the mean distances between any of the groups (Cruz, 2001).

\section{RESULTS AND DISCUSSION}

The multivariate analyses using Jaccard's coefficient confirmed the high genetic similarity between varieties Cravo and Pêra $(74.5 \%)$, and consequently, the $F_{1}$ hybrids being studied $(74.2 \%$ to $99.7 \%$ ) (Oliveira et al., 2002). Such high similarity level made it difficult to obtain polymorphic markers between parents. The RAPD reactions, performed with 102 primers, provided the amplification 640 consistent fragments, of which only $226(35.3 \%)$ were polymorphic. Between markers, due to progeny segregation, 100 heterozygous loci were verified in 'Pêra' sweet orange ( $a a \times A a), 46$ in 'Cravo' mandarin $(\mathrm{Aa} \times \mathrm{aa})$ and 80 in both parents $(\mathrm{Aa} \times \mathrm{Aa})$. Taxonomically, the species $C$. sinensis and $C$. reticulata are classified as closely related (Cooper, 1990; Davies \& Albrigo, 1994; Luro et al., 1995), and many authors suggest that $C$. sinensis is a hybrid between $C$. reticulata and $C$. maxima (Federici et al., 1998).

The bidimensional dispersion graph demonstrates the expected tendency for an intermediate distribution of $F_{1}$ hybrids relative to parents (Figure 1). Undoubtedly, using a significant number of RAPD markers (226) allowed for a precise estimation of distances between genotypes. A knowledge of the presence/absence of these markers in the species $C$. maxima will elucidate the hypothesis of origin of $C$. sinensis from $C$. reticulata

A structural simplification of the RAPD data was obtained through the principal components analysis, providing a better comparison of the genetic divergence between parents and hybrids, in view of a graphical evaluation that is easy to interpret. From 96 principal components obtained, the first four accumulated only $54.9 \%$ of the total variation, and ten components were necessary to reach $81.3 \%$ of the variance (Table 1). One single pair of components was not sufficient to represent the dispersion of the parents and their hybrids in a consistent way, since the variance was distributed among the first ten principal components. 
The genetic divergence between parents and hybrids was represented by the first four principal components, in two bidimensional graphs, Figure 2, a and $b$, and a nearly random distribution of the hybrids in relation to the parents is suggested. Thus, based on their positions in the dispersion graphs, the hybrids can be classified as:

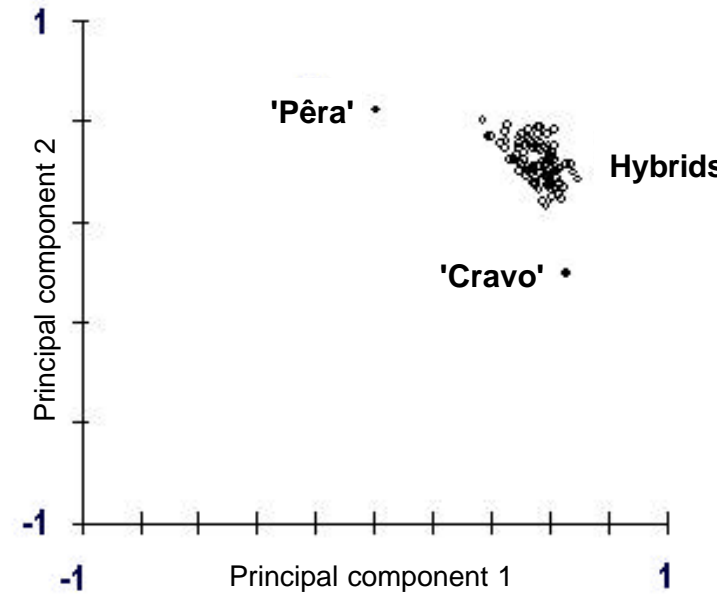

Figure 1 - Bidımensıonal graphical aispersıon of genetic distances of $94 \mathrm{~F}$, hybrids relative to their parents $C$. sinensis (L.) Osbeck cv. Pêra and C. reticulata Blanco cv. Cravo.
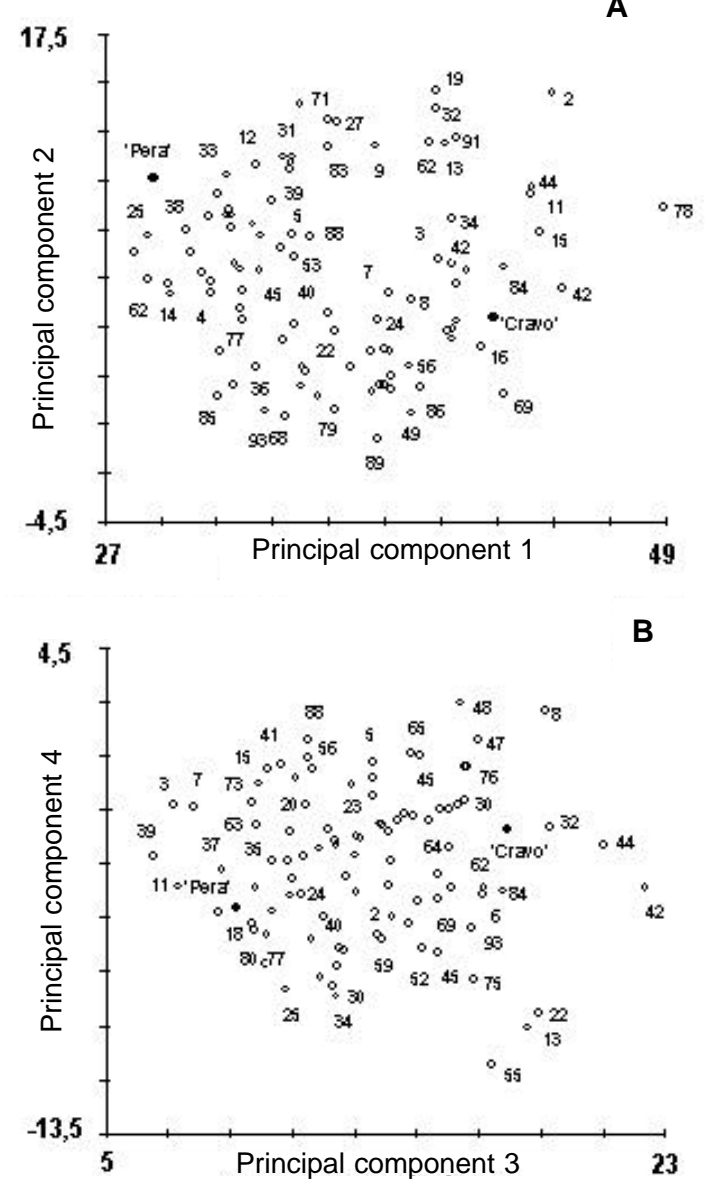

Figure 2 - Bidimensional graphical dispersion between genetic distances of parental C. sinensis (L.) Osbeck cv. Pêra and $C$. reticulata Blanco cv. Cravo, and $94 F_{1}$ hybrids, obtained by principal components analysis. The hybrids were partially identified. hybrids with an intermediate genetic distance between the parents, hybrids with high genetic similarity relative to one of the parents, hybrids quite different from both parents, and hybrids with high similarity among themselves. Even though there were hybrids very similar between themselves, no twins were found, which could occur in citrus, due to polyembryony by cleavage of the sexual embryo or by the existence of more than one normal gametophyte in the ovule (Frost \& Soost, 1968). The fact that Citrus species in general present high heterozygosity can explain the existence, in some cases, of zygotic individuals having very significant differences relative to both parents (Moreira \& Pio, 1991). This aspect is evidenced by the presence of a considerable number of markers (80) in heterozygosis in the parents ( $\mathrm{Aa} \times \mathrm{Aa}$ ), which resulted in approximately $25 \%$ of hybrids with recessive homozygous genotype (aa) for each of these markers.

The comparison of results provided by the dispersion of genotypes (Figure 2) demonstrates great variation in genetic divergence between parents and hybrids in view of the principal components that were utilized. There was no precise positioning of the hybrids among themselves and relative to the parents by this multivariate analysis method, and this probably occurred because of the nature of the utilized RAPD markers, which have a low correlation level among themselves because independent segregation occurs, preventing the total variance from being explained by a reduced number of principal components. Therefore, this kind of analysis had little applicability in the genetic divergence study of the examined $F_{1}$ progeny.

The Tocher optimization method (Rao, 1952) was utilized to verify the existence of clusters of genotypes based on their genetic similarity. Thus, thirty groups of materials showing similarity were obtained, with 12 groups composed by a single genotype (Table 2). Group 1 , where the parental 'Pêra' sweet orange was included, whose source could be hybrid (Federici et al., 1998), showed the largest number of genotypes (19) (Table 2).

Table 1 - Principal components of genetic distances between C. sinensis (L.) Osbeck cv. Pêra, C. reticulata Blanco cv. Cravo and $94 \mathrm{~F}_{1}$ hybrids.

\begin{tabular}{lccc}
\hline $\begin{array}{l}\text { Principal } \\
\text { component }\end{array}$ & $\begin{array}{c}\text { Authovalue } \\
\text { estimative }\end{array}$ & $\begin{array}{c}\text { \% of each } \\
\text { component }\end{array}$ & $\begin{array}{c}\text { Accumulated } \\
\text { percent }\end{array}$ \\
\hline 1 & 19.1 & 19.9 & 19.9 \\
2 & 16.2 & 16.8 & 36.8 \\
3 & 9.7 & 10.2 & 46.9 \\
4 & 7.7 & 8.0 & 54.9 \\
5 & 6.3 & 6.5 & 61.4 \\
6 & 5.6 & 5.9 & 67.3 \\
7 & 5.2 & 5.4 & 72.7 \\
8 & 3.8 & 3.9 & 76.7 \\
9 & 2.5 & 2.6 & 79.2 \\
10 & 2.1 & 2.1 & 81.3 \\
\hline
\end{tabular}


Table 2 - Groups presenting similarity determined by the Tocher optimization method, resulting from genetic distance analysis between 'Pêra' sweet orange (C. sinensis (L.) Osbeck), 'Cravo' mandarin (C. reticulata Blanco) and $94 \mathrm{~F}_{1}$ hybrids.

\begin{tabular}{ll}
\hline Group & \multicolumn{1}{c}{ Parientals and/or hybrids } \\
\hline 1 & 'Pêra' sweet orange, 14, 17, 23, 25, 26, 33, 38, \\
& $43,46,50,59,64,65,70,71,76,81,92$ \\
2 & 'Cravo' mandarin, 69, 74 \\
3 & $6,9,22,28,30,52,67,68,85,93$ \\
4 & $1,7,35,37,39,53,60,88,94$ \\
5 & $31,47,48,51,75,79$ \\
6 & $12,19,27,57,83$ \\
7 & $18,49,80,89$ \\
8 & $40,66,77,90$ \\
9 & $56,63,73,82$ \\
10 & $3,11,15$ \\
11 & $61,72,84$ \\
12 & 4,45 \\
13 & 8,21 \\
14 & 10,29 \\
15 & 24,34 \\
16 & 36,58 \\
17 & 42,44 \\
18 & 54,87 \\
\hline
\end{tabular}

Even though the work was made with a representative amount of RAPD markers (226), which provided a widespread genome coverage without being affected by environmental factors (Ferreira \& Grattapaglia, 1998), the false tendency of occurrence of greater genetic similarity of hybrids relative to the parents with a higher number of $\mathrm{loci}$ in heterozygosity, when working with dominant markers, should not be discarded (Lynch \& Milligan, 1994; Luro et al., 1995).

A considerable degree of correspondence can be verified between genotypes grouped by the Tocher method and those that are closer together in the dispersion graph, according to the principal components analysis (Table 2 and Figure 2a). The results given by these two types of analyses are complementary, providing additional support for a better understanding of the genetic relationships between the genotypes under study.

At present, the hybrids are being evaluated under screen-caging and field conditions in relation to the phenotypic variability of several agronomically important traits, whit the purpose of understanding their inheritance and selecting promising hybrids.

\section{REFERENCES}

COOPER, W.C. Odyssey of the orange in China; natural history of the Citrus fruits in China. Lake Alfred: E. O. Painter, 1990. 122p.

CRUZ, C.D. Programa GENES - versão windows; aplicativo computacional em genética e estatística. Viçosa: UFV, 2001.648p.

CRUZ, C.D.; REGAZZI, A.J. Modelos biométricos aplicados ao melhoramento genético. Viçosa: UFV, Imprensa Universitária, 1994. $390 p$.

DAVIES, F.S.; ALBRIGO, L.G. Citrus. Wallingford: CAB International, 1994 $254 \mathrm{p}$.

DIAS, L.A.S. Divergência genética e fenética multivariada na predição de híbridos e preservação de germoplasma de cacau (Theobroma cacao L.). Piracicaba, 1994. 94p. Tese (Doutorado) - Escola Superior de Agricultura "Luiz de Queiroz", Universidade de São Paulo.

FEDERICI, C.T.; FANG, D.Q.; SCORA, R.W.; ROOSE, M.L. Phylogenetic relationships within the genus Citrus (Rutaceae) and related genera as revealed by RFLP and RAPD analyses. Theoretical and Applied Genetics, v.96, p.812-822, 1998

FERREIRA, M.E.; GRATTAPAGLIA, D. Introdução ao uso de marcadores moleculares em análise genética. 3.ed. Brasília: EMBRAPA CENARGEN, 1998. 220p.

FROST, H.B.; SOOST, R.K. Seed reproduction; development of gametes and embryos. In: REUTHER, W.; BATCHELOR, L.D.; WEBBER, H.J. (Ed.) The citrus industry. Berkeley: University of California Press, 1968. v.2, p.290-324.

GROSSER, J.W.; GMITTER JR., F.G. Somatic hybridization of Citrus with wild relatives for germplasm enhancement and cultivar development. HortScience, v.25, p.147-151, 1990.

HUFF, D.R.; PEAKALL, R.; SMOUSE, P.E. RAPD variation within and among natural populations of outcrossing buffalograss [ Buchloe dactyloides (Nutt.) Engelm.] Theoretical and Applied Genetics, v.86, p.927-934, 1993.

LINK, W.; DIXKENS, C.; SINGH, M.; SCHWALL, M.; MELCHINGER, A.E. Genetic diversity in European and Mediterranean faba bean germplasm revealed by RAPD markers. Theoretical and Applied Genetics, v.90, p.27-32, 1995

LURO, F.L; BOVÉ, F.L.; BOVÉ, J.M.; OLLITRAULT, P. DNA amplified fingerprinting; a useful tool for determination of genetic origin and diversity analysis in Citrus. HortScience, v.30, p.1063-1067, 1995.

LYNCH, M.; MILLIGAN, B.G. Analysis of population genetic structure with RAPD markers. Molecular Ecology, v.3, p.91-99, 1994

MOREIRA, C.S.; PIO, R.M. Melhoramento de citros. In: RODRIGUEZ, O. VIEGAS, F.; POMPEU JR., J.; AMARO, A.S. (Ed.) Citricultura brasileira 2.ed. Campinas: Fundação Cargill, 1991. v.1, p.116-152.

OLIVEIRA, R.P.; CRISTOFANI, M.; AGUILAR-VILDOSO, C.I.; MACHADO, M.A. Diversidade genética entre híbridos de tangerina 'Cravo' e laranja 'Pêra' utilizando marcadores RAPD. Pesquisa Agropecuária Brasileira, v.37, p.479-484, 2002.

PEARSON, K. On lines and planes of closest fit to systems of points in space. Philosophical Magazine, v.2, p.559-572, 1901

RAO, R.C. Advanced statistical methods in biometric research. New York: John Wiley, 1952. 390p.

SNEATH, P.H.A.; SOKAL, R.R. Numerical taxonomy; the principles and practice of numerical classification. San Francisco: W.H. Freeman, 1973 $573 p$.

WILLIAMS, J.G.K.; KUBELIK, A.R.; LIVAK, K.J.; RAFALSKI, J.A.; TINGEY S.V.; DNA polymorphisms amplified by arbitrary primers are useful as genetic markers. Nucleic Acids Research, v.18, p.6531-6535, 1990.

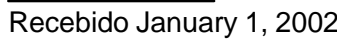

